\title{
TECHNOLOGY AND INNOVATION
}

\section{THE EFFECT OF PECTOLYTIC ENZYME TREATMENTS OF MERLOT RED GRAPE MASHES ON THE MICROBIOLOGICAL QUALITY OF WINES}

\author{
KIRO MOJSOV \\ Technological-Technical Faculty, \\ University “Goce Delcev”, Macedonia
}

UDC: $579.66: 579.67+663.2$

Key words: Pectolytic enzymes, red grape Merlot, microbiological quality of wines, microbial spoilage in wine.

\begin{abstract}
The paper investigates effects of pectolytic enzyme treatments of red grape mashes on the microbiological quality of wines and wine stability with counting of the presence yeast cells (Saccharomyces cerevisiae), after incubation on Sabourald-maltose agar. Also wine samples were investigated for the presence of moulds and other bacteria, including dangerous bacteria Salmonella and Shigella, Staphylococus aureus, Proteus spp., Sulphite-reducing clostridy and Escherichia coli.

All wine samples the results showed the presence of yeasts Saccharomyces cerevisiae. Saccharomyces is regarded as spoilage organism only if it is found in the wrong place at the wrong time (e.g. in a bottle of semi-sweet wine) causing re-fermentation. Pectinolytic enzyme preparation Trenolin Rot DF showed the best results.

Pectolytic enzyme treatments of red grape mashes had a pronounced effect on the microbiological quality of wines and wine stability. Results from comparison of effects of pectolytic enzyme preparations in winemaking on the microbiological quality of wines can contribute to a better orientation in the choice of suitable enzyme preparations in wine industry.
\end{abstract}

Source: Mojsov K., 2012. "The effect of pectolytic enzyme treatments of Merlot red grape mashes on the microbiological quality of wines", Perspectives of Innovations, Economics \& Business, Vol.11(2), pp.110-116, http://dx.doi.org/10.15208/pieb.2012.11

\section{Introduction}

Merlot is a darkly blue-coloured variety of wine grape, which used in the making of red wine. Merlot grapes are mostly used to make Merlot wine, but they are also used in association with other grapes to make some remarkable wine blends. Merlot grapes are grown in many regions around the world such as France, Italy, Bulgaria, Romania, Australia, New Zealand, California, Washington and British Columbia.

Merlot grapes is cultivated and in Republic of Macedonia. It is wine grape which used in the making of red high quality wines in this country. Although the composition of the grape depends on its variety, the soil and the climatic conditions, there is little variation in the actual cell structure of the plant.

Enzymes play a definite role in the ancient and complex process of winemaking. From the pre-fermentation stage, through fermentation, post- 
fermentation and aging, enzymes are the major driving forces catalysing various biotransformation reactions (Van Rensburg and Pretorius, 2000). Pectolytic enzyme preparations have been used for over 60 years in fruit juice production. These enzymes play a mayor role in fruit juice technologies. Protopectinases, polygalacturonases, lyases and pectin esterases are among the extensively studied pectinolytic enzymes.

Protopectinases catalyze the solubilization of protopectin. Polygalacturonases hydrolyze the polygalacturonic acid chain by addition of water and are the most abundant among all the pectinolytic enzymes. Lyases catalyze the trans-eliminative cleavage of the galacturonic acid polymer. Pectinesterases liberate pectins and methanol by de-esterifying the methyl ester linkages of the pectin backbone. The largest industrial application of pectinases is in fruit juice extraction and clarification. Pectinolytic enzymes added to macerated fruits before the addition of wine yeast in the process of producing red wine resulted in improved visual characteristics (colour and turbidity) as compared to the untreated wines. Enzymatically treated red wines presented chromatic characteristics, which are considered better than the control wines. These wines also showed greater stability as compared to the control (Revilla and Gonzalez-San Jose, 2003).

The winemaking process is a complex ecological niche where the biochemistry and interaction of yeasts, bacteria, fungi and the viruses play a pivotal role in the final product. These microorganisms involved are at the core of the winemaking process, whether for good or ill (Du Toit and Pretorius, 2000). The main microorganisms associated with wine spoilage are yeasts, acetic acid bacteria and lactic acid bacteria. Winemaking processes include multiple stages at which microbial spoilage is likely to occur. One must attemt to reduce the numbers of microbes in the juice and on the equipment. This is achieved through processing the pulp by applying food hygiene practices and following the hazard analysis critical control point (HACCP) system. The second stage of microbial spoilage may occur during fermentation because at this stage, the fruit juice contains both the natural flora of the fruit and fora that may be harboured by the wine cellar and its equipment. This may render the wine unacceptable, since the spoilage can include bitterness and offflavours (mousiness, ester taint, phenolic, vinegary, buttery, etc.), as well as cosmetic problems such as turbidity, viscosity, sediment and film formation. The major spoilage organisms of the yeast genera include Brettanomyces, Candida, Hanseniaspora, Pichia and Zygosaccharomyces. The genera of lactic acid bacteria include Lactobacillus, Leuconostoc and Pediococcus, while the acetic acid bacteria genera are Acetobacter and Gluconobacter (Du Toit and Pretorius, 2002).

The spoilage caused by yeasts is important because they cause refermentation, ester formation, hydrogen sulphide and volatile sulphur compounds, volatile acidity, the formation of volatile phenols, mousiness, film formation, deacidification and the formation of ethyl carbamate. Saccharomyces is regarded as spoilage organism only if it is found in the wrong place at the wrong time (e.g. in a bottle of semi-sweet wine) causing refermentation. Schizosaccharomyces pombe has been associated with wine spoilage when growing in bottled wine and forming a sediment at the bottom of the bottle (Boulton et al., 1996). 
The spoilage caused in wine by lactic acid bacteria is associated particularly with acetification of the wine through the production of acetic acid, mousy taints, bitterness, ropiness, buttery flavour and increased viscosity of the wine (Shimazu and Watanabe, 1981; Zoecklein et al., 1995).

The main spoilage caused by acetic acid bacteria is associated with oxidation of the ethanol to acetaldehyde and eventually acetic acid. Gram-negative acetic acid bacteria require oxygen for growth. They carry out incomplete oxidation of alcohols, leading to the accumulation of organic acids as end products (Amerine et al., 1980; Bartowsky and Henschke, 2004).

As it is known, yeasts play an essential role in the spoilage of beverages. A few species are capable of spoiling beverages. They can survive and grow under stress conditions where other microorganisms are not competitive. This study uses the wine industry as a case study where serious microbiological problems are caused by yeasts. The effect of pectolytic enzyme treatments on red grape mashes are discussed in connection with the microbiological quality of wines, the susceptibility of wine to spoilage yeasts and wine stability based on scientific knowledge and industrial practices for monitoring yeast contamination i.e. for monitoring the presence of yeast.

\section{Material and method}

\section{Commercial pectolytic enzyme preparations}

- Vinozym Vintage FCE, Novozymes A/S, Bagsvaerd, Denmark; 2, 3, 4, and $5 \mathrm{~g} / 100 \mathrm{~kg}$ grapes

- Rohapect VR-C, AB Enzymes GmbH, Darmstadt, Germany; 2, 3, 4, and 5 $\mathrm{g} / 100 \mathrm{~kg}$ grapes

- Trenolin Rot DF, Erbslöh Geisenheim AG, Geisenheim, Germany); 10, 15, 20 , and $25 \mathrm{ml} / 100 \mathrm{~kg}$ grapes

- These enzyme preparations are derived from cultures of Aspergillus niger which is a species accepted as G.R.A.S. (Generally Recognized As Safe) (Canal-Llauberes, 1993).

\section{Grape samples for laboratory trials}

The grape cultivar Merlot (Vitis vinifera), cultivated in the Ovce pole vineyard, the Povardarie region, was harvested at optimal maturity (2009 vintage), at 200-220 $\mathrm{g} \mathrm{l}^{-1}$ sugar, 6.5-7.5 $\mathrm{g} \mathrm{l}^{-1}$ total acids, and $\mathrm{pH}$ from 3.1 to 3.3 , and transported to the private winery "Imako Vino" Stip, Republic of Macedonia.

\section{Wine samples. Microvinification}

Wines were prepared in the laboratory of winery "Imako Vino" Stip. Grapes was weighed, crushed/destemmed and divided in 5 liters plastic fermentation tanks. Red grape mashes were macerated for 6 hours $\left(18-20{ }^{\circ} \mathrm{C}\right)$, with addition on one commercial pectolytic enzyme preparation. After addition of $\mathrm{SO}_{2}(5 \mathrm{O}$ ppm) and yeast (Saccharomyces cerevisiae) NEUTRE SC (Lallemand)(200 mg $\mathrm{kg}^{-1}$ grape), was applied maceration time of 5 days $\left(\sim 25{ }^{\circ} \mathrm{C}\right)$. After the 
maceration, the pomace was removed. All wines were plunged twice daily to completion of fermentation. Control trial was in all same with experimental trials only no added pectolytic enzyme preparation. All treatments were performed in duplicate.

The bottled wines $(0.5 \mathrm{l})$ were stored at $4-6^{\circ} \mathrm{C}$.

\section{Determination of the total yeast cells}

The effect of pectolytic enzyme treatments on red grape mashes on the microbiological quality of wines and wine stability were investigated with counting of the presence of yeast cells (Saccharomyces cerevisiae), after incubation on Sabourald-maltose agar.

$1 \mathrm{ml}$ wine sample was added to Sabourald-maltose agar base for yeasts and moulds in petri dish. After keeping the samples at room temperature (thermostat) for 3-5 days were counted the presence yeast cells (cells $/ \mathrm{ml}$ wine).

Sabouraud-maltose agar: peptone (1.0\%), maltose (4.0\%), agar (2.0\%).

\section{Determination of bacteria}

Salmonella and Shigella, Staphylococus aureus, Proteus spp., Sulphitereducing clostridy and Escherichia coli.

Salmonella and Shigella in $25 \mathrm{ml} .25 \mathrm{ml}$ wine sample was added in Erlenmeyer with $225 \mathrm{ml}$ Selenite broth. After keeping the samples at $37{ }^{\circ} \mathrm{C}$ (thermostat) for 24 hours with eza were transplanted at SS base for Salmonella and Shigella and placed $24-48$ hours at $37^{\circ} \mathrm{C}$.

Selenite broth: peptone (0.5\%), lactose (0.4\%), Na-selenite (0.4\%), Naphosphate (1.0\%).

Staphylococus aureus in $0.1 \mathrm{ml} .1 \mathrm{ml}$ wine sample $+9 \mathrm{ml}$ physiological solution $=10 \mathrm{ml}$ wine solution

$1 \mathrm{ml}$ from wine solution are put at BAIRD PARKER base for Staphylococus aureus, and are keep in thermostat 24 hours at $37^{\circ} \mathrm{C}$.

BAIRD PARKER AGAR: tryptone (1.0\%), meat extract (0.5\%), $\mathrm{LiCl}(0.5 \%)$, yeast extract (0.1\%), agar (2.0\%).

Proteus spp. in $0.1 \mathrm{ml} .1 \mathrm{ml}$ from wine solution are put at SS base for Proteus spp., and are keep in thermostat $24-48$ hours at $37^{\circ} \mathrm{C}$.

SS agar: peptone (5.0 g), meat extract (5.0 g), lactose (10.0 g), egg salts (8.5 $\mathrm{g})$, natrium citrate $(8.5 \mathrm{~g})$, natrium thiosulphate $(3.5 \mathrm{~g})$, ferric citrate (1.0 g), agar (13.0 g), neutral red (0.023 g), brilliant green (0.00033 g).

Sulphite-reducing clostridy in $0.1 \mathrm{ml} .1 \mathrm{ml}$ from wine solution are put at sulphite agar base for Sulphite-reducing clostridy, and are keep in thermostat 24-48 hours at $37^{\circ} \mathrm{C}$.

Sulphite-reducing bacteria usually produce black colonies as a result of the reduction of sulphite to sulphide, which reacts with the iron(III)salt.

Sulphite agar: tryptone (15.0 g), yeast extract (10.0 g), distilled water (750 $\mathrm{ml}$ ), water (aqua fontis) $(250 \mathrm{ml})$.

Escherichia coli in $10 \mathrm{ml}$. $10 \mathrm{ml}$ from wine solution are put at liquid MAC CONKEY base $(5 \mathrm{ml})$ for Escherichia coli, and are keep in thermostat 24-48 
hours at $44{ }^{\circ} \mathrm{C}$. After this, with eza are transplants at pink red egg yolk agar, and are keep in thermostat $34-48$ hours at $44^{\circ} \mathrm{C}$. Escherichia coli grow as red or pink colonies.

MAC CONKEY AGAR: peptone (20.0 g), synthetic detergent (5.0 g), sodium chloride (5.0 g), lactose (10.0 g), neutral red (0.07 g), agar (12.0 g).

\section{Results and discussion}

Yeasts and bacteria are part of the natural microbial ecosystem of wine and play an important role in winemakingby reducing wine acidity and contributing to aroma and flavour. They can cause numerous unwelcome wine spoilage problems, which reduce wine quality and value.

Enzymes play an important role in winemaking. The application of industrial enzyme preparations in the wine industry is a common practice. They have been used to increase juice yield, filtration rate, rate of settling, and clarity of wines besides some microbiological implications.

TABLE 1. THE EFFECT OF PECTOLYTIC ENZYME TREATMENTS OF RED GRAPE MASHES ON THE MICROBIOLOGICAL QUALITY OF WINES

\begin{tabular}{|c|c|c|c|}
\hline $\begin{array}{l}\text { Enzyme } \\
\text { preparations }\end{array}$ & $\begin{array}{c}\text { Dose (g or } \\
\text { ml/10okg } \\
\text { grape) }\end{array}$ & $\begin{array}{c}\text { aYeasts, } \\
\text { Saccharomyces } \\
\text { cerevisiae } \\
\text { (cells } / \mathrm{ml} \text { ) }\end{array}$ & $\begin{array}{c}\text { 'Bacteria, } \\
\text { Salmonella and Shigella; } \\
\text { Staphylococus aureus; } \\
\text { Escherichia coli; Sulphite- } \\
\text { reducing clostridy;Moulds } \\
\text { and other bacteria, } \\
\text { (cells/ml) }\end{array}$ \\
\hline \multirow{4}{*}{$\begin{array}{l}\text { Vinozym Vintage } \\
\text { FCE }\end{array}$} & $2 \mathrm{~g}$ & $983 \pm 41$ & 0 \\
\hline & $3 g$ & $933 \pm 47$ & 0 \\
\hline & $4 g$ & $733 \pm 47$ & 0 \\
\hline & $5 \mathrm{~g}$ & $680 \pm 19$ & 0 \\
\hline \multirow[t]{4}{*}{ Rohapect VR-C } & $2 \mathrm{~g}$ & $1817 \pm 82$ & O \\
\hline & $3 \mathrm{~g}$ & $1813 \pm 66$ & 0 \\
\hline & $4 g$ & $1700 \pm 82$ & 0 \\
\hline & $5 \mathrm{~g}$ & $1833 \pm 52$ & $\mathrm{O}$ \\
\hline \multirow[t]{4}{*}{ Trenolin Rot DF } & $10 \mathrm{ml}$ & $370 \pm 33$ & 0 \\
\hline & $15 \mathrm{ml}$ & $435 \pm 23$ & 0 \\
\hline & $20 \mathrm{ml}$ & $524 \pm 34$ & 0 \\
\hline & $25 \mathrm{ml}$ & $587 \pm 34$ & 0 \\
\hline $\begin{array}{l}\text { Control-no } \\
\text { added enzyme }\end{array}$ & 0 & $483 \pm 47$ & O \\
\hline
\end{tabular}

The largest industrial application of pectinases is in fruit juice extraction and clarification. Pectinolytic enzymes added to macerated fruits before the addition of wine yeast in the process of producing red wine resulted in improved visual characteristics (colour and turbidity) as compared to the untreated wines. These wines also showed greater stability as compared to the control (Revilla and Gonzalez-San Jose, 2003). The concepts of the susceptibility of wine to spoilage yeasts and wine stability are based on scientific knowledge and industrial practices for monitoring yeast contamination. A discussion on acceptable levels of yeasts and microbiological 
criteria in the wine industry is supported by data obtained from wineries, wholesalers, and the scientific literature.

The effect of pectolytic enzyme treatments on red grape mashes on the microbiological quality of wines and wine stability were investigated with counting of the presence yeast cells (Saccharomyces cerevisiae), after incubation on Sabourald-maltose agar, as shown in Table 1.

In all wine samples the results showed that have yeasts Saccharomyces cerevisiae from 300 to 2000 cells $/ \mathrm{ml}$. Saccharomyces is not regard as spoilage organism only if it is found in the wrong place at the wrong time (e.g. in a bottle of semi-sweet wine) causing re-fermentation, meanwhile the better is to have less. Pectinolytic enzyme preparation Vinozym Vintage FCE showed yeasts Saccharomyces cerevisiae from 680 to 983 cells/ml wine, Rohapect VR-C from 1700 to 1833 cells $/ \mathrm{ml}$, and Trenolin Rot DF from 370 to 587 cells $/ \mathrm{ml}$ depend of used doses and contol trial "no-enzyme addition" (483 cells/ml). Pectinolytic enzyme preparation Trenolin Rot DF showed the best results.

Analysis of all wine samples did not find the growth of unwanted bacteria as Salmonella and Shigella, Staphylococus aureus, Proteus spp., Sulphitereducing clostridy and Escherichia coli.

\section{Conclusion}

Significance and impact of the study is that pectolytic enzyme treatments on red grape mashes had a pronounced effect on the microbiological quality of wines and wine stability. Results from comparison of effects of pectolytic enzyme preparations in winemaking on the wines microbiological quality can contribute to a better orientation in the choice of suitable enzyme preparations in wine industry.

Acknowledgement: We are acknowledge on two Private Winerys. Many thanks to Risto Ljubotenski, owner on Prvate Winery "Imako vino" Stip (Macedonia), for support, providing the grapes and permit for conducting laboratory trials in his winery. Also many thanks for producers on enzyme preparations Novozymes (Denmark), Erbslöh (Germany), and AB Enzyme (Germany) for the delivered enzyme preparations.

\section{References}

Amerine, M., Kunkee, R., Ough, C., Singleton, V. and Webb, A., 1980. The technology of wine making, (4th Ed), AVI Publishing Co. Inc: Westport, Connecticut

Bartowsky, E. and Henschke, P., 2004. "Acetic acid bacteria and wine: All is well until oxygen enters the scene,” Aust. N.Z. Grapegrower Winemaker , 485a, pp.86-91

Boulton, R., Singleton, V., Bisson, L. and Kunkee, R., 1996. Principles and practices of winemaking, New York: Chapman\&Hall

Canal-Llaubères, R., 1993. "Enzymes in winemaking," In: Fleet, GH. (Ed.), Wine microbiology and biotechnology, Philadelphia: Harwood Academic Publishers

Du Toit, M. and Pretorius, I., 2000. "Microbial Spoilage and Preservation of Wine: Using weapons from nature'own arsenal. A review," South African Journal of Enology and Viticulture, Vol.21, pp.74-96

Du Toit, M. and Pretorius, I., 2002. "The occurrence, control and esoteric effects of acetic acid bacteria in winemaking," Annals of Microbiology, Vol.52, pp.155-79 
Revilla, I. and Gonzalez-San Jose, M., 2003. "Addition of pectolytic enzymes: an enological practice which improves the chromaticity and stability of red wines," Int. J. Food Sci. Technol., Vol.38, pp.29-36

Shimazu, Y. and Watanabe, M., 1981. "Effects of yeast strains and environmental conditions on forming organic acids in must during fermentation,” J. Ferment. Technol., Vol.59, pp.27-32

Van Rensburg, P. and Pretorius, I., 2000. "Enzymes in winemaking: harnessing natural catalysts for efficient biotransformations. A review," South African Journal of Enology and Viticulture, Vol.21, pp. 52-73

Zoecklein, B., Fugelsang, K., Gump, B. and Nury, F., 1995. Wine analysis and production. New York: Chapman and Hall Enology Library 